МЭДЭЭЛЭЛ

\title{
МОНГОЛ УЛС ХХ ЗУУНЫ ОЛОН УЛСЫН ХАРИЛЦААНЫ ТОГТОЛЦООНД: ТУУХЧ, ДИПЛОМАТЧ Ц. БАТБАЯР
}

Ю.В.Кузьмин

2017 оны 12 дугаар сард Түүхийн шинжлэх ухааны доктор, Онц бөгөөд Бүрэн эрхт элчин Цэдэндамбын Батбаяр 60 нас хүрч байна. Ц.Батбаяр бол XX зууны эхний хагасын Монгол-Японы дипломат харилцаа, Монгол-Орос, Монгол-Хятадын харилцааны түүх, Монгол ба Их гүрнүүдийн харилцааны түүх, түүн дотор 1939 оны Халх голын дайны түүх, уг дайны өмнөх үеийн улс төр-дипломатын харилцааны түҮх, уг сурвалж, мөн чанарыг судалсан Монголын томоохон түүхч эрдэмтдийн нэгэн билээ. Тэрбээр 1981 оноос ШУА-ийн Дорнодахин, Олон улс судлалын хүрээлэнд, 1998 оноос Монгол Улсын Гадаад явдлын яаманд олон арван жил, үр бүтээлтэй, хичээл зүтгэлтэй ажиллаж байгаа дорнодахины судлаач, туршлагатай дипломатч хүн.

Монгол, ОХУ, Япон болон гадаадын бусад орны дорнодахины болон монгол судлаачдын дунд Ц.Батбаяр мэргэжлийн өндөр түвшинд бэлтгэгдсэн дорнодахины судлаач, авъяаслаг эрдэмтэн хэмээх нэр хүндийг олж, түүний эрдэм шинжилгээний ном, өгүүллүҮд Монгол, ОХУ, Япон, АНУ зэрэг улсын архивын баримт материал, эх сурвалжид тулгуурласан, түүхийн асуудлыг гүн гүнзгий задлан шинжилж, өөрийн гэсэн өвөрмөц үнэлэлт дүгнэлт өгсөн байдгаараа онцгой ялгардаг билээ. Тэрбээр орос, англи, япон, хятад зэрэг гадаад хэлийг сайтар эзэмшиж, ОХУ, Япон, БНХАУ, АНУ зэрэг олон оронд эрдэм шинжилгээний болон дипломат ажил эрхэлж, онолын мэдлэг болон практик ажлын туршлагыг нягт нямбай хослуулж чадсан болно. Тэрбээр ШУА-ийн Дорнодахин, Олон улс судлалын хүрээлэнд 1981-1998 онд ЭША, эрдэмтэн нарийн бичгийн 
дарга, улмаар захирлаар дэвшин ажиллаж, Монгол Улсад Ази судлал, дорнодахины судлалыг хөгжүүлэн бэхжүүлэхэд тодорхой хувь нэмрээ оруулжээ.

Амжилт бүтээлтэй ажиллах, мэргэжлээр ахин дэвших чухал нөхцөл нь чанартай боловсрол эзэмшсэн байх явдал байдаг. Цэдэндамбын Батбаярт 1970-аад онд тэр үеийн ЗХУ-ын шилдэг дээд сургуулийн нэгэнд мэргэжлийн өндөр түвшинд дорнодахины судлаачийн боловсрол олж авах таатай боломж олдсон байдаг. Тухайн үед ШУА-ийн Ерөнхийлөгчөөр ажиллаж байсан Б.Ширэндэвийн томилолтоор Ленинградын /өдгөөгийн Санкт Петербургийн/ Их сургуулийн дорнодахины факультетын Алс Дорнодын орнуудын түүхийн тэнхимд 1976-1981 онд суралцан төгсчээ. Тухайн тэнхим нь Хятад, Япон, Солонгос, Монгол зэрэг Зүүн Азийн орнуудын түүхээр мэргэжсэн дорнодахины судлаач-түүхчдийг бэлтгэдэг олон зуун жилийн уламжлалтай Зөвлөлтийн шилдэг сургуулийн нэг байв. Ц.Батбаяр япон орон судлал, япон судлаачаар дагнан мэргэжихийн зэрэгцээ япон, орос, англи, хятад хэлийг сайтар эзэмшиж, дорнодахины судлаач-түүхчийн суурь боловсролыг олж, их сургуулиа онц дүнтэй нэр хүндтэй төгссөн нэгэн.

Ленинградын Их сургуулийн Алс Дорнодын орнуудын түүхийн тэнхимд нанхиадч Г.Я.Смолин, Л.А.Березный, Б.Г.Доронин, Б.Н.Мельниченко, Японы мэргэжилтэн Л.В.Зенина, Б. Ковригин зэрэг нэрт эрдэмтэд, дорнодахины судлаачид багшилж байлаа. Тус тэнхим цөөхөн оюутантай байсан нь гадаад хэл, дорнодахины түүхийн чанартай, суурь боловсрол олгох үндсэн нөхцөл байв. Дорнодахины тэнхим нь суурь судлал, эх сурвалж, түүх бичлэгт илүY их цаг зарцуулж, тэр чиглэлийн мэргэжилтэн бэлтгэхэд онцгой анхаардаг байсан нь Ленинградын сургуулийн нэг онцлог болно. Ц.Батбаяр оюутны жилүүдийнхээ тухай “Би 1976-1981 онд Ждановын нэрэмжит Ленинградын Их сургуульд суралцсан билээ. Хэдийгээр би японы түүхээр дагнасан авч, эхний хоёр гурван жил япон хэлийг сайтар эзэмшихэд ихээхэн цаг хугацаа, эрч хүчээ зарцуулсан юм. Япон хэлний тэнхимд А.А.Бабинцев, Д.П.Бугаева, Г.С.Максимова зэрэг ажил мэргэжилдээ бүх амьдралаа зориулсан багш нар ажиллаж байлаа. Япон хэлний хэдэн мянган ханз үсэг заавал цээжлэх шаардлага тавьж, ярианы япон хэлийг ч өндөр 
түвшинд Японоос уригдан ирсэн багш нараар заалгаж байлаа. Манай ангид Москвагийн хэдэн охид, Казанийн нэг татар бүсгүй, Вьетнамын оюутан Фам Ван Хок нар байсан. Хэл сурах чадвараараа би тэднээс хамаагүй давуу. Гэхдээ вьетнам оюутан тун их шаргуу суудаг, ажилсаг. Москвагийн охид ч сүрхий сурлагатай, тэд дэндүү их зугаалж наргидаг байснаа сүүлдээ бусдаас сүүлдэхгүйг хичээн ихэд хичээллэдэг болж билээ” хэмээн дурсажээ.

Дорнодахины факультетийн Алс Дорнодын орнуудын түүхийн тэнхим профессор багш нарынхаа мэргэжлийн лут ур чадвараар төдийгүй, оюутан аспирант нарт хатуу чанд шаардлага тавьж, курс, дипломын ажлыг хамгаалахад тэнхим бүрэн бүрэлдэхүүнээрээ оролцож, профессор юм уу доцент курсын ажлыг шүүмжлэн дүгнэдэг байснаараа алдартай байв. Оюутан, аспирант хүндэтгэн үзэх шалтгаангүй ганц хоёр цагийн хичээл тасалбал тэнхимээр авч хэлэлцэнэ. Иймд цөөн тооны 5-6 оюутан дагнасан мэргэжлээр 5 жил суралцахад 3-4 оюутан л шигшигдэн төгсөж, тэд мэргэжлээ өндөр түвшинд эзэмшээд цаашдаа Их сургуулийн профессор, эрдэм шинжилгээний ажилтан, дипломат болдог байлаа. Кузьмин миний бие 1980-85 онд тус тэнхимд профессор Лев Абрамович Березныйн удирдлагаар аспирантурт суралцаж төгссөн тул тус тэнхимыг сайн мэдэх билээ. Тэнхимын профессор багш нар өндөр соёлтой уран бүтээлч маргаан хэлэлцүүлэг өрнүүлдэг, оюутан аспирант нарыг хувь хүнийх нь хувьд хүндэлдэг, тэднийг Дорнодахины орнуудын түүх, соёл, уламжлал, ёс заншлыг гүнээ сонирхон судалдаг, жинхэнэ Петербургийн сэхээтэн болгохыг ихэд хичээдэг байж билээ.

Ц.Батбаяртай цуг Монголын бусад олон оюутан сурч байснаас хожмын нэрт эрдэмтэд, улс төрчид, дипломатууд болцгоосон бөгөөд тухайлбал, ШУА-ийн Олон улсын харилцааны хүрээлэнгийн захирал, түүхийн ШУ-ны доктор Ж.Баясах, тус хүрээлэнгийн тэргүүлэх ажилтан, түүхийн ухааны доктор Н.Ариунгуа, МУИСийн ОУХНУ-ын сургуулийн зөвлөх багш, профессор Н.Алтанцэцэг, авъяаслаг археологч асан Г.Мэнэс, Онц бөгөөд Бүрэн эрхт Элчин сайд Б.Батхишиг, Б.Энхмандах, УИХ-ын дэд дарга Ц.Нямдорж нарыг дурьдаж болно. Тэр үед эх орноосоо алсад суугаа монгол оюутнууд найрсаг нөхөрсөг, харилцан бие биедээ туслах аятай тохитой нөхцлийг бүрдүүлж сурцгааж байв. Нева мөрний тэр сайхан хотод 
Монгол Улс XX зууны олон улсын харилцааны тогтолцоонд: Түүхч, дипломатч Ц.Батбаяр

Батбаяр ирээдүйн амьдралын үнэнч хань Ленинградын хөгжмийн дээд сургуулийн оюутан Пунцагийн Доржпагамтай танилцан ханилан сууснаар түүний амьдралын гол чухал үйл явдал болсон байна.

Батбаярын төгсөх дипломын ажлын сэдэв нь “Өвөр Монгол дахь Японы булаан эзлэх бодлого, Дэмчигдонров вангийн тоглоомын Засгийн газар /1933-1945 он/" нэртэй ажил байсан бөгөөд тэрхүу сэдэв нь түүний дараачийн жилүүдэд XX зууны эхэн хагасын Монгол-Японы түүхэн харилцааг судлах гол сонирхсон сэдвийг өдөөж өгсөн байна. Ленинградын Их сургуулийн нэрт япон судлалын профессор Л.В.Зенина түүний дипломын ажлыг удирдаж, хятад судалын профессорууд Г.Я.Смолин, Л.А.Березный нар зөвлөгөө өгч, тэрбээр Ленинград, Москвагийн дорнодахины ном судраар арвин олон нэртэй номын санд ажиллаж, ирээдүйн эрдмийн их ажлыг шимтэн судлах хөрс сууриа тавьж авчээ.

Ц.Батбаяр Ленинградын Их Сургуулийг 1981 онд улаан дипломтай онц төгсөж ирээд ШУА-ийн Дорнодахины хүрээлэнд эрдэм шинжилгээний дадлагажигч ажилтнаар орж ажлын гараагаа эхэлжээ. Тухайн үед Дорнодахины хүрээлэнгийн захирлаар академич Ш.Бира, дэд захирлаар академич Н.Ишжамц, эрдэмтэн нарийн бичгийн даргаар академич Ч.Далай ажиллаж, Дорнодахины хүрээлэн ЭТНБХ-ны байранд байрладаг байлаа. Дорондахины хүрээлэнгийн удирдлага залуу эрдэмтний авъяас чадварыг өндрөөр үнэлж, ЗХУ-д шууд аспирантурт суралцуулахаар санал нэгтэй шийдсэн байна. Түүнд 1984-1987 онд ЗХУ-ын ШУА-ийн Алс Дорнодын хүрээлэнгийн шууд аспирантурт суралцаж түүхийн ухааны докторын зэргийг хамгаалах боломж гарав. Ц.Батбаяр аспирантурт сурсан талаараа "Тухайн үед ШУА-ийн Алс Дорнодын хүрээлэн орчин үеийн хятад судлалаар Зөвлөлтдөө төдийгүй, дэлхийд нэртэй томоохон төв байлаа. Тус хүрээлэнг Оросын нэрт нанхиадч академич М.Л.Титаренко удирдаж байв. Би анхандаа түүх бичлэгээр түүхийн ухааны докторын зэрэг хамгаалахаар Ленинградын Их сургуульд хуваарилагдсан байв. Тэр намар академич Ч.Далай Москва явахаар болж нэг галт тэргэнд билет авч хоёул хамт явсан юм. Зам зуур Далай академичийн докторын ажлын зарим бүлгийг монголоос орос хэл рүҮ орчуулах ажлыг нь чадан ядан хийж, тус дэм болж явав. Москвад 
очоод Далай гуайн хамт Алс Дорнодын хүрээлэнд очиж, Москвад үлдэж аспирантурт суралцах боломжтой эсэхийг лавлан асуув. Тэд сэдвээ орчин үеэр болгож өөрчлөхийг зөвлөсний дагуу “ӨМӨЗОны талаарх ХКН-ын удирдлагын бодлогын үндсэн чиглэлүүд /19761984 онд/" хэмээн сэдвээ өөрчилж Мосвад аспирантурт суралцахаар болсон юм" гэж дурссан байна.

Батбаярын түүхийн ухааны дэд эрдэмтэн буюу одоогийнхоор $\mathrm{PhD}$ докторын ажлыг “Түвдийн ард түмний түүхэн найруулал" зохиолоороо Дорнодахины судлаачдад танил болсон нэрт түвдэч эрдэмтэн В.А.Богословский удирдах болов. Тэрбээр Дорнодахин, Түвдийн түүхийн нарийн ширийн, сонин содон зүйлийг нэвтэрхий мэддэг, өөрийн салбартаа олны хүлээн зөвшөөрсөн нэр хүндтэй том эрдэмтэн байв. Тэр үед Алс Дорнодын хүрээлэнд БНХАУ-ын үндэстний цөөнхийн байдлыг судалдаг жижгэвтэр сектор ажиллаж, тэр секторт В.А.Богословский нараас гадна Хятадын үндэстний цөөнх, тэдний хэл шинжлэлийн томоохон мэргэжилтэн А.А.Москалев ажиллаж байв. Аспирантурын 3 жил ч дорхноо өнгөрч, Батбаяр Лениний номын сан, ИНИОН хэмээх нийгмийн ухааны төрөлжсөн номын сан зэрэгт ихэнхи цагаа өнгөрөөхийн зэрэгцээ Оросын нийслэл Москва хотын түүх дурсгалын газрууд, музей, театруудтай танилцаж байв. Алс Дорнодын хүрээлэнгийн эрдмийн танхимд түүний хамгаалалт болж, Өвөр Монголын асуудлаар мэргэшсэн нэрт хятад судлаач, монголч эрдэмтэн С.Д.Дылыков албан ёсны шүүмжлэгчээр оролцов. Алс Дорнодын хүрээлэнгийн захирал Титаренко эрдмийн зэргээ гялалзтал хамгаалсан Монголын залуу эрдэмтэнд баяр хүргэж, түүний өгүүллийг “Проблемы Дальнего Востока” сэтгүүлд нийтлэх саналыг тавьж, түүний бүтээлийг өндөр үнэлсэн юм.

Москвагийн аспирантурт суралцсан нь түүний дорнодахины судлаачийн боловсрол, цаашид мэргэжлээр ахиж дэвшихэд нэн чухал мэдлэг боловсрол нэмсэн, тун таатай түлхэц болж өгчээ. Москва, Петербургийн дорнодахины судлалын сургуулиуд чиглэл, зорилтоороо нэн ялгаатайг тэмдэглэл зохино. Петербургийн сургууль Зүүн Азийн орнуудын эртний, дундад зууны, шинэхэн түүх, түүх бичлэгийг илүY их дагнадаг бол Москвагийн сургууль XX зууны түҮх, ялангуяа Азийн орнуудын орчин үеийн үйл явц, дипломат 
Монгол Улс ХХ зууны олон улсын харилцааны тогтолцоонд: Түүхч, дипломатч Ц.Батбаяр

харилцаа, улс төр судлал, өнөөгийн гадаад бодлогыг үндсэн чиг баримжаагаа болгон судалдаг байна. Иймд аспирант Батбаярын хувьд Дорнодахины орнуудын түүх, соёлоос гадна, орчин цагийн үйл явцыг танин мэдэх, задлан шинжлэх, улам гүнзгийрүүлсэн төсөөлөлтэй болох сайхан бололцоог олгосон гэж хэлж болно.

1987 оноос Ц.Батбаяр ШУА-ийн Дорнодахины судлалын хүрээлэнд ЭША-аар ажиллаж, Монгол-Америкийн эрдэмтдийн Зүүн Азийн бүс нутгийн асуудлаар Улаанбаатарт болсон анхны эрдэм шинжилгээний бага хуралд илтгэл тавьж, АНУ-ын нэрт Ази судлаачид Роберт Скалапино, Харри Хардинг, Канадын эрдэмтэн Роберт Бедески нартай олон жилийн нөхөрлөлийн эхийг тавьсан байна. Тэрбээр 1989-90 онд Осака хотын гадаад судлалын Их сургуульд нэг жил япон судлалаар мэргэжил дээшлүүлж, япон хэл, Японы соёл, зан заншилтай ойртон танилцах боломж олдсон байна.

Тэрбээр 1990-98 онд ШУА-ийн Дорнодахин, олон улс судлалын хүрээлэнгийн захирлын нэр хүндтэй албыг хашив. Тухайн үедээ 33 настай ШУА-ийн хүрээлэнгийн захирлууд дотор хамгийн залуу захирал байлаа. Энэ он жилүүд бол ШУА-ийн тогтолцоог шинэчлэн зохион байгуулах, зах зээлийн цоо шинэ орчинд дасан зохицох, Монгол Улсын шинжлэх ухаан дэлхийн шинжлэх ухааны орчин, арга барилд шилжин орох нэн төвөгтэй он жилүүд байв. Түүний удирдлагаар хүрээлэнгийн эрдэмтэд Япон болон “Азийн бар” орнуудын эдийн засгийн хөгжлийн туршлага, ОХУ, БНХАУ дахь монгол угсаатны түүх, орчин үеийн байдлын судалгаа, Монголын олон тулгуурт гадаад бодлогын онол, практикийн асуудлууд зэрэг шинэ сэдвүүдээр судлагаа хийж, шинэлэг хамтын бүтээлүүд гаргажээ. Япон, Хятад, ОХУ-ын эрдэмтэдтэй хамтран хэд хэдэн олон улсын судалгааны төсөл хэрэгжүүлэв.

Залуу эрдэмтэн Халх голын байлдааны 50 жилийн ойгоор "Халхын гол: Түүх ба орчин үе" /УБ., 1989/ хэмээх номоо хэвлүүлж, ХХ зууны гучаад оны олон улсын харилцааны тогтолцоо, учир шалтгаан, хувьсал өөрчлөлтийг задлан шинжилжээ. Халхын голд 1939 онд болсон цэргийн мөргөлдөөнийг тун нухацтай үнэлж дүгнэж, “Халхын гол уу, Номонхан уу?” хэмээх “Улаан Од” сонинд хэвлүүлсэн нийтлэл нь Монголын хэвлэлд өргөн олны анхаарлыг ихэд татаж байсан билээ. Нэг сэдэвт бүтээлээ хуучны уламжлалт байр 
суурианаас бичиж бэлтгэсэн авч, 1939 оны байлдааны өмнөх Халхын гол орчимд хилийн байрлал, Халх-Баргын хил, хил хязгаарын яриа хэлэлцээ, дипломат түүхийн нарийн ээдрээтэй, маргаантай олон асуудлыг дээрх бүтээлдээ хөндөж өөрийн санал бодлоо илэрхийлжээ. Халхын голын дайны сэдэв, уг дайны дипломат түүхийг Монголын эрдэмтэн маань тэгэсхийгээд орхисонгүй, удтал үргэлжлүүлэн судласаар ирсэн болно. Дэлхийн II их дайны босгон дээрх цэрэг, дипломатын үйл явдлыг Монголын түүх бичлэгт анх түрүүлж өөрийнхөөрөө тайлбарлан цоо шинэ санаа санал дэвшүүлсэн билээ.

1990-ээд орны дундуур, 2000 оны эхээр Ц.Батбаяр Япон, АНУ-д удаан хугацаагаар эрдмийн ажил хийсэн байна. 1993 онд Хитоцубаши Их сургуульд Танака Кацухико профессортой цуг, 1996-97 онд Токиогийн Гадаад судлалын их сургуульд Наками Тацүо профессортой цуг судалгааны ажил хийж, 2001-2002 онд АНУын Вудро Вильсоны нэрэмжит олон улсын судалгааны төвд зочин судлаачаар тус тус уригдан ажилласан байна. Хөгжилтэй орнуудын Ази, Дорнодахины судлалын эрдэм шинжилгээний байгууллага, архивын баримт хэрэглэгдэхүүн, бусад гадаад орны томоохон эрдэмтэн мэргэд, шинжлэх ухааны судалгааны арга барилтай гүн гүнзгий ултай танилцаж, эрдэм шинжилгээний хэлхээ холбоо тогтоожээ. Түүнчлэн олон улсын харилцааны тогтолцоо, “Монголын асуудлаархи" Өрнө, Дорнын орнуудын ижил төстэй мөн ялгаатай байр суурь, Монгол Улс, түүний өнгөрсөн үе хийгээд дэлхийн хөгжлийн хэтийн төлөв, өнөөгийн ертөнц дэхь Монголын эзлэх байр суурийг орчин үеийн эрдэмтэд хэрхэн үздэгийг түүхч эрдэмтэн маань яаж төсөөлдөгөө улам өргөтгөн баяжуулах боломжтой болов.

Ц.Батбаяр Монгол, Хятад, Японы түүх, орчин үеийн байдал, Монгол-Япон, Монгол-Орос, Монгол-Хятадын харилцааны түүхийн олон тулгамдсан асуудлаар 10 гаруй нэг сэдэвт зохиол, 15 орчим хамтын бүтээл нийтлүүлжээ. Түүний бүтээл зохиолыг Монгол, ОХУ, Япон, Хятад, АНУ, Энэтхэг болон бусад оронд орчуулан хэвлэсэн нь түүхчийн эрдэм судлалын ажлыг үр дүнг гадаад дотоодод гарцаагүй хүлээн зөвшөөрсөн гэж үзүүштэй. Түүний томоохон бүтээлүүдээс дурьдвал: "Халхын гол: Түүх ба Орчин үе” /УБ., 1989/, "Кодама, Мицуй пүүс, Хүрээнд байсан япончууд” /УБ., 1993/, “Монгол ба Япон XX зууны эхэн хагаст: Монголын улс төрийн гадаад 
Монгол Улс XX зууны олон улсын харилцааны тогтолцоонд: Түүхч, дипломатч Ц.Батбаяр

харилцааны түүхээс" /УБ., 1998/, “Монгол ба Их гүрнүҮд ХХ зууны эхэн хагаст” /УБ., 2006/, “Богд хаант Монгол Улс гуравдахь хөршийн эрэлд” /УБ., 2011/, “Монгол ба Япон ХХ зуунд” /УБ., 2012/, “Амар сайд, Сэцэн хан нар 1925 онд Хятадад зорчсон нь: Банчэн Богд, Фын Юйсян, Ли Дажао" /УБ., 2015/ зэргийг дурдаж болно. Түүний үнэлгээ дүгнэлт нь түүхийн эх сурвалж, архивын баримт сэлтийг ул нухацтай задлан шинжилж, түүхийн үйл явдлыг олон талаас нь авч үзэж нарийн шүүлтүүрээр шүүн гаргасан байдаг. Зохиол бүтээл нь товч тодорхой үг найруулгатай, яг оносон, нарийн шалгасан томъёололтой, логик дэс дараатай, итгэл үнэмшил сайтай байдгаараа онцлогтой.

Ц.Батбаярын ном бүтээлд Монголын улс төр-дипломатын түүхийн үйл явдал, сэдэв ухагдахууныг Монголын гадаад бодлогын өнөөгийн тулгамдсан асуудалтай нягт нямбай, оновчтой хослуулж чадсан байдгаараа онцлогтой. Гадаад бодлогын үзэл баримтлал нь хэрхэн яаж түүхийн үүднээс бүрэлдэн тогтсон, хувьсан өөрчлөгдөж ирсэн уламжлалыг гүн гүнзгий мэддэг нь орчин цагийн гадаад бодлогын тулгамдсан зорилтыг тодорхойлох, үнэлэх, Монгол Улсын өнөөгийн гадаад бодлогыг төлөвлөн зохицуулах ажлыг эрдэм шинжилгээний үндэстэй явуулах бололцоог түүнд олгодог байна.

Тэрбээр 1998 онд эрдэм судлалын олон жилийн нөр их ажлын үр дүн болох "Монгол, Японы харилцаа XX зууны тэргүүн хагаст" бүтээлээрээ Монголдоо түүхийн шинжлэх ухааны докторын зэрэг амжилттай хамгаалсан билээ. УГ бүтээлийг Монголд төдийгүй ОХУ, АНУ, Японд өндөр үнэлж, дэлхийн нэртэй монголч эрдэмтэд М.Гольман, В.Грайворонский, Х.Фүтаки, К. Этвүүд нар нэг сэдэвт зохиолыг сайшаасан шүүмж бичиж байлаа. Олон улсын монголч эрдэмтдийн удаа дараагийн их хуралд Ц. Батбаяр өөрийн судлалын үндсэн сэдвүүдээр сонирхолтой илтгэлүүд бэлтгэн байнга оролцож ирснээр дэлхийд танигдсан Монголын эрдэмтний нэг зүй ёсоор болсон юм. Эрдэмтний эрдэм шинжилгээний бүтээл, орчуулгын номуудыг мэргэжлийн хүмүүс төдийгүй Монголын өргөн олон уншигчид андахгүй сайн мэддэг болж, тэрбээр XX зууны түүхийн мэдээлэл, орчин үеийн гадаад бодлогын асуудал, ололтыг идэвхтэй сурталчлан таниулагч боллоо.

Ц.Батбаяр “Монгол ба Япон XX зууны эхэн хагаст” нэг сэдэвт 
зохиолоо 1998 онд Улаанбаатарт эх хэлээр, 2002 онд Улаан Үдэд орос хэлээр хэвлүүлсэн билээ. Орос эхийг монголоос орос хэл рүY орчуулан хэвлэлд бэлтгэхэд Монгол Улсаас ОХУ-д сууж байсан Элчин сайд, эрдэмтэн Ц.Гүрбадам тусалж дэмжсэн байна. Ц.Батбаярын суурь боловсрол япон орон судлал учраас түүний зохиол өвөрмөц, бүтээлч агуулгатай болжээ. 1900-1945 оны МонголЯпоны харилцааны нэн ээдрээтэй түүхийн олон чухал зангилаа асуудлыг дэвшүүлэн гаргаж, өөрийн гэсэн өвөрмөц гаргалгаa дүгнэлт хийсэн байна. Хаант Орос болон империалист Япон Зүүн Азид нөлөөний хүрээгээ хэрхэн хувааж байсан, 1911 онд Халх Монгол тусгаар тогтнолоо зарласныг Токио юу гэж үзсэн, Богд эзэн хаанаас Японы цог жавхлант эзэн хаанд явуулсан элч нар, түүний захидлын хувь заяа юу болсон, 1910, 20-иод оны Нийслэл Хүрээнд япончууд хэрхэн ирж суурьшсан, юу эрхэлж байсан, Японы цэрэг, худалдааныхан Монголын зах зээлийг яагаад сонирхох болсон зэрэг олон асуудлыг нарийвчлан авч үзжээ. Судлаач Монгол, ОХУ, Хятад, Япон, АНУ-ын архивт удаа дараа сууж ажиллаж, ХХ зууны Зүүн Азийн олон улсын харилцаанд Монгол Улс ямархуу жин дарж байсныг архивын баримт сэлтээр хөдөлшгүй нотлон харуулжээ. Тэрбээр Японы Гадаад харилцааны архив, Батлан хамгаалах газрын архивт уйгагүй ажиллаж, Монголын XX зууны түүхтэй холбогдолтой олон арван материалыг шинээр илрүүлж, эрдэм шинжилгээний эргэлтэд анх удаа оруулсан гавъяатай гэж хэлж болно.

Ц.Батбаяр өмнөд хөрш БНХАУ-д дипломат ажлаар нийтдээ 6 жил хагас ажиллажээ. Тэрбээр 2003-2006 онд Монгол Улсаас БНХАУ-д суугаа ЭСЯ-нд зөвлөхөөр, 2009-2013 оны эхэн хүртэл Элчин зөвлөх буюу ЭСЯ-ны дэд тэргүүнээр ажилласан байна. БНХАУ-тай харилцах нь орчин үеийн Монгол Улсын тухайд улс төр, ялангуяа гадаад эдийн засгийн харилцааны нэн чухал харилцаа байдаг. Тэрбээр өмнөд хөрш оронд ажиллах хугацаандаа энэ орны хагжлийн бодит байдалтай ойроос танилцаж, БНХАУ-ын дотоод, гадаад бодлого, өнөөгийн Хятад гүрний дипломат ажлын зарчмыг гүнзгийрүүлэн судлах, Монгол-Хятадын түүхийн асуудлаар хятадын эрдэмтдийн бичсэн ном зохиолыг нягтлан судлах боломж олж авчээ. Цаг завгүй их эрч хүч шаардах дипломат ажлын хажуугаар судалгааны ажилд цаг зарцуулах боломж хомс байсан боловч тэрбээр цагаагчин гахай 
жилийн хувьсгалын 100 жилийн ойгоор 2011 онд “Богд хаант Монгол Улс гуравдахь хөршийн эрэлд” номоо хэвлүүлж, Хятадын нэрт дипломат Цянь Цичэнийн “Хятадын дипломатийн 10 томоохон үйл явдал” номыг орчуулах төслийг Бээжинд санаачлан эхлүүлж, өнөөгийн Нинься мужийн Люпаньшан ууланд сүүлчийн зунаа зуссан Чингис хааны холбогдолтой нутгаар аялж, “Чингис хааны сүүлчийн зун” хэмээх баримтат киног найруулагч Д. Хишигттэй хамтран бүтээсэн байна.

Монгол-Хятадын харилцааны түүхтэй салшгүй холбогддог Хятадын төр, цэргийн зүтгэлтнүүд болох Юань Шикай, Жан Золин, Сүнь Ятсэн, Чан Кайши нарын намтар, Монголтой холбогдох учир шалтгааныг нарийн судалсан нь 2015 онд “Амар сайд, Сэцэн хан нар 1925 онд Хятадад зорчсон нь” номоо бичихэд таатай хөрс бүрдүүлж өгчээ. Тэрбээр уг зохиолдоо 1920-иод оны дундуур Ардын Засгийн Ерөнхий сайдын орлогч А.Амар, Сэцэн хан Навааннэрэн нарын түшмэд Бээжинд Ли Дажао, Банчэн Богд нартай, Хаалганд хятадын маршал Фын Юйсянтай уулзсан сонин содон түүхийг шинэ сэргэг баримт сэлтээр сэргээн баяжуулж бичжээ.

Ц.Батбаярын "Монгол ба их гүрнүүд XX зууны эхний хагаст" /2006, 2015 он/ хэмээх суурь судалгааны нэг сэдэвт бүтээл бол $\mathrm{XX}$ зууны тэргүYн хагасын Монгол Улсын гадаад харилцаа, геополитикийн орчныг онцгой өвөрмөц аргаар задлан шинжилсэн томоохон туурвил мөн. Тухайн хагас зуун жилийн олон улсын харилцааны тогтолцоо хийгээд ЗСБНХУ, Хятад, Япон, АНУ-тай харилцахдаа Монгол Улс ямар бодлого барьж, юуг эрхэмлэж байв, Зүүн Хойд Азийн олон улсын харилцааны түүхэн үйл явц ямар их нарийн түвэгтэй, зөрчил будлиантай байдгийг харуулж, Монголын тусгаар тогтнол, монголчуудын тусгаар тогтнолоо байлдан олж авсан тэмцэл зөрчлийг олон талаас нь нягтлан дүгнэжээ. Монголын эрдэмтний энэхүҮ ном Монгол, ОХУ, Япон, АНУ, Тайванийн архивын сан хөмрөгт хадгалагдаж буй олон зуун баримт сэлтийг эрдэм шинжилгээний эргэлтэд оруулсан, бүхэл бүтэн төгс боловсруулсан цогц судалгаа болж чаджээ. Энэ бол монголын эрдэмтдийн XX зууны түүхийн судалгааны зарчмын нэгэн үе шат, Монголын гадаад харилцаа, геополитикийн орчин, бүс нутгийн олон улсын харилцааны тогтолцооны түүхийг Монгол-ЗСБНХУ-Хятад-Япон хэмээх дөрвөн 
хэмжээст талаас нь тайлбарласан судалгааны цоо шинэ түвшинг илтгэсэн бүтээл болой.

Бүхэлдээ Монголын нэрт, томоохон түүхчдийн нэг Ц.Батбаярын судалгаа бол баримт материалыг нарийн бодож боловсруулсан, авцалдаа уялдаа сайтай бүтэц агуулгатай, монгол хэлний тод сайн найруулгатай, эмх цэгцтэй бичиж туурвисан байдгаараа онцгой ялгардаг. Тэрбээр эрдэм шинжилгээний бүтээл туурвихдаа архивын баримт сэлтийг урьтал болгодог, түүхийн асуудлыг хөнгөн хийсвэрээр бичилгүй, хөдөлшгүй баримт сэлтээр нотлон харуулж, шинэ сэргэг санаа оноог ямагт дэвшүүлж, түүндээ нийцсэн баримт хэрэглэгдэхүүнийг логик уялдаатай ашиглаж чаддаг нь түүний бүтээл зохиолын цар хүрээг илтгэн харуулдаг.

Цэдэндамбын Батбаяр Монголын нэрт дорнодахины судлаачтүүхч төдийгүй олны танил болсон дипломатч бөгөөд 1998 оноос Монгол Улсын гадаад харилцааны албанд амжилттай, үр бүтээлтэй ажиллаж байна. Тэрбээр 1998 оны 12 дугаар сард ГХЯ-ны Нэгдсэн бодлогын газрын даргаар Монгол төрийн гадаад харилцааны албанд ажлын гараагаа эхэлсэн юм. 1998-2000 онд Монгол төрийн гадаад бодлогыг төлөвлөх, зохицуулах, Зүүн Ази, Зүүн Хойд Азийн бүс нутгийн улс төр, аюулгүй байдлын шинэ бүтцүүдэд нэгдэн орох, анхны “Гадаад бодлогын хөх ном"-ыг бэлтгэх зэрэг олон чухал ажлыг амжуулсан байдаг. Ц.Батбаяр 2006-2009, 2013-2014 онд ГАЯ-ны Бодлого төлөвлөлт, мэдээллийн газрын захирлаар удаа дараа ажиллаж, АСЕМ, АПЕК, ПЕКК зэрэг бүс нутгийн бүтэц, хөтөлбөрүүдэд нэгдэн орох, хамтран ажиллах, Зүүн Хойд Азийн аюулгүй байдлыг бэхжүүлэхэд Монгол Улсын хувь нэмрийг оруулах “Улаанбаатарын яриа хэлэлцээ" жил бүрийн чуулга уулзалтыг санаачлан анхны уулзалтыг 2014 онд Улаанбаатарт зохион байгуулсан байна.

Тэрбээр эрдэм шинжилгээний хурал, чуулга уулзалтыг даргалахдаа асуудлаа бүрэн эзэмшиж, англи, орос, япон зэрэг хэлээр чөлөөтэй ярьдаг нь Монголын эрдэмтэн, дипломатчийн ур чадварыг харуулдаг. АНУ-ын Принстоны Их сургууль /1995/, Индианы Их сургууль /2002/, Жон Хопкинсийн Их сургууль /2015, 2016/, Японы Токиогийн гадаад судлалын Их сургууль /1996/, Бээжингийн Их сургууль/2006/ зэрэг дэлхийн олон их дээд сургуульд уригдан лекц 
уншиж, олон улсын хурал симпозиумд оролцож байв.

Ц.Батбаяр хувь хүнийхээ хувьд өндөр боловсролтой, оюунлаг, түшиг тулхтай анд нөхөр, гэр бүлдээ ихэд анхааран халамжилдаг хань, гурван хүүхдийн эцэг, зургаан ач зээгийн буурал аав бөгөөд үр хүүхэд, ач зээ нараа амжилттай явах болгонд Батбаяр болон түүний хань Хөгжим бүжгийн дээд сургуулийн профессор Доржпагам нар баярлаж байдаг нь ойлгомжтой.

Тэрбээр Монголын орчин үеийн нэрт дорнодахины судлаачтүҮхчийн нэг болж, түүхчид, олон улс судлаачид, монголын дипломатчид, мэргэжил нэгтнүүдийнхээ дунд хүлээн зөвшөөрөгдөж, итгэл найдварыг олсон эрдэмтэн, дипломатч билээ. Монголын төр засаг түүний ажил хөдөлмөрийг үнэлж, 2007 онд Алтан гадас одонгоор, 2011 онд Хөдөлмөрийн гавьяаны улаан тугийн одонгоор тус тус шагнажээ. 2016 онд Монгол Улсын Ерөнхийлөгчийн зарлигаар “Онц бөгөөд Бүрэн эрхт Элчин” дипломат дээд цолоор шагнуулсан байна.

Эх нутгаасаа алсад Латин Америк, Карибын тэнгисийн орон Кубын нийслэл Хаванад Монгол Улсаа төлөөлөн Онц бөгөөд Бүрэн эрхт Элчин сайдаар сууж буй Ц. Батбаяртаа Монгол төрийн гадаад харилцааны нэр хүндтэй алба, эрдэм номын ажилдаа цаашид их ном бүтээл, шинэ шинэ ололт амжилт олохын өлзийтэй ерөөлийг мэргэжил нэгт нөхөд нь өргөн дэвшүүлж байна.

ЭрхуҮ хот. 2017.10.10. 